Article

\title{
Investigating the Users' Approach to ICT Platforms in the City Management
}

\author{
Francesco Caputo * and Leonard Walletzký \\ Department of Computer Systems and Communication, Masaryk University, Brno 602 00, Czech Republic; \\ qwalletz@fi.muni.cz \\ * Correspondence: fcaputo@mail.muni.cz; Tel.: +39-3921-809-686
}

Academic Editors: Francesco Polese, Luca Carrubbo and Orlando Troisi

Received: 27 November 2016; Accepted: 3 January 2017; Published: 6 January 2017

\begin{abstract}
The increasing relevance of technology and its impact on our everyday life requires multi- and trans-disciplinary studies in order to investigate the ways in which the Information and Communication Technology (ICT) tools are affected by users' features and by the external environment. In order to enrich existing contributions on this topic, the paper focuses its attention on the city as example of service systems, in order to investigate dimensions and dynamics that influence the city employees' evaluation and satisfaction in the use of ICT platforms. By adopting the interpretative lens offered by Service Science and Systems Thinking, the domain of city as a service system is analysed and some hypotheses are formulated with reference to the relationships between environment, users, and ICT platform. The hypotheses are investigated through a questionnaire survey on a sample of 1032 municipalities in the Czech Republic and the results are tested using Structural Equation Modelling. The research shows that users' features and external environment affect the evaluation and the satisfaction of city stakeholders about the use of ICT platforms by underlining the need for enlarging the study on informatics tools, in order to also include subjective variables. The findings are discussed from both theoretical and practical points of view.
\end{abstract}

Keywords: users' perceptions; ICT platforms; service system; service science; systems thinking

\section{Introduction}

In a challenging paper of 2011, Nam and Pardo [1] wrote that 'smartness in the technology context implies the automatic computing principle like self-configuration, self-healing, self-protection, and self-optimization. Smart homes, smart buildings, and larger smart ensembles like airports, hospitals or university campuses are equipped with a multitude of mobile terminals and embedded devices as well as connected sensors and actuators. Smart ecosystem is a conceptual extension of smart space from the personal context to the larger community and the entire city' (p. 283).

This short definition offers an interesting description of the world in which we all live; a world in which more of the physical boundaries that have affected past generations have completely disappeared [2-4]; a world in which all the developments, evolutions, and advancements in knowledge are strictly related to the application of Information and Communication Technologies (ICTs) and digital tools [5-10].

The world in which we daily live appears to have really few connections with the world of our grandfathers [11]. The emerging digital era is radically changing every kind of social and economic dynamics by defining new rules and balances [12]. In such a line, several researchers and practitioners have tried to offer indications, suggestions, and comments about the possible ways to face the challenges of digital era [13-15]. They have analysed the role of technologies in social and economic development [16], the approaches in evaluating the utility of new technologies in specific 
domains [17], and the possible pathways to use new technologies to solve new problems or past problems in better ways [18].

Despite the relevance of all these contributions, they offer an objective view of technology as possible levers to 'use' to solve specific problems [19]. This description does not consider the role of human resources in the management of technology, and it offers few indications about the influence of users' perceptions in the application of ICT platform and about the ways in which 'external conditions' affect the users' evaluation and satisfaction in the use of ICT platforms.

With reference to this, a relevant advancement in knowledge has been offered by Parasuraman [20] with the concept of 'technology readiness' in terms of 'people's propensity to embrace and use new technologies for accomplishing goals in home life and at work' (p. 308). This concept underlines the need for including in the evaluation of ICT platforms the users' ability to use them, and it opens up a wider research domain, with reference to the relationship between computer and social sciences.

In order to enrich the previous managerial contributions about the role of users and environment in the application and utility of ICT platforms, this paper adopts the interpretative lens offered by Service Science [21-25] and Systems Thinking [26-32], with the aim to investigate the following research question: In which way do users' perceptions and the structural configuration of external environment affect the users' level of satisfaction and the users' evaluations about the ICT platforms?.

In order to enrich previous knowledge about this topic, this paper focuses its attention on the domain of city as example of a Service System in which ICT platforms have a relevant role in ensuring the information sharing and the service delivery to and with the citizens [33]. According to this, this paper investigates the perceptions of a sample of 1032 city employees in the Czech Republic and it aims to investigate, through Structural Equation Modelling (SEM), if there are relationships among the structure of the city in terms of localization (region) and number of citizens, the kind of used platforms, the city size, and the level of satisfaction in the use of ICT platform. At the same time, the research also aims to test the relationship between the level of satisfaction in the use of ICT platforms and the users' evaluations of these platforms.

In a nutshell, this paper is structured as follows; in Section 2, the conceptual and theoretical backgrounds are analysed and some hypothesis are stated. In Section 3, the method is described and the SEM is used to test the proposed hypotheses. In Section 4, the results are presented, and, in Section 5, they are discussed both from a theoretical and from a practical point of view. Finally, in Section 6, some conclusions and future directions for the research are proposed.

\section{Conceptual and Theoretical Background}

\subsection{A smart Service View of Cities and Citizens}

According to Holston [34], 'the city is a special site for such formation and re-formation of citizens' (p. 14). By adopting this definition, to build a wider conceptual framework about the domain of city, it is possible to underline the need for including both physical and cognitive elements. More specifically, the city can be considered a complex domain in which people, structures, infrastructures, goods, services, and institutions interact in order to achieve several, and, at the same time, conflicting aims [35-37]. In such a line, the description of the city can be linked with the definition of ecosystem offered by Lusch [38] in terms of 'spontaneously sensing and responding spatial and temporal structure of largely loosely coupled value proposing social and economic actors interacting through institutions and technology, to: (1) coproduce service offerings; (2) exchange service offerings and (3) cocreate value' (p. 15).

Effectively the city can be considered a tangible example of ecosystem in which knowledge, skills, and competences are exchanges through the service delivery processes, thanks to the support offered by technology [1,39-43]. In such a line, as underlined by Maglio and Spohrer [22], technology can be considered the instrument to support the emergence and managing of service systems. In the same 
direction, [44,45] show the great relevance of technology in ensuring the functioning of city services and the citizens' satisfaction.

By focusing their attention on the role of technology in the domain of city management, several researchers have analysed its application [46], effects [47], and processes [48]. According to all these contributions, it is possible to state that the contribution of technology to the management of the city is strictly affected by the informatics features [49].

In such a scenario, Gurstein [50] shows that different kinds of technologies or, better, different kinds of ICT platforms can have different impacts on the effectiveness of city management. This relationship is affected both by the ability of users involved in the management of the city and by the specific features of technology [51]. By recognizing the relevance of this topic in the study of city management, this paper aims to investigate the following hypothesis:

Hypothesis $\mathbf{1}\left(\mathbf{H}_{\mathbf{1}}\right)$ : There is a relationship between the kind of ICT platform used and the city employees' satisfaction with the use of these platforms.

By following the study about the role of ICT platforms in the management of city as a service system, a relevant topic that requires investigation refers to the domain of user satisfaction [52]. More specifically, several contributions have analysed this domain with reference to the actors involved in the service ecosystem [53,54], and some advancements in knowledge have been proposed, also with reference to the citizens' satisfaction [55]. According to Brady et al. [56], the large part of the studies about satisfaction in the domain of service systems refer to five constructs' 'sacrifice, service quality, service value, customer satisfaction, and behavioural intentions' (p. 215). These constructs describe the dimensions of user satisfaction, and they can be extended to all the service domains. More specifically, these constructs offer 'tangible' elements on which reflect in order to define possible instruments to measure the users' evaluation [57]. The basic idea is that, by measuring the users' evaluation about a service, it is possible to have a 'quantification' of users' satisfaction [58]. In order to verify this relationship with reference to the city employees involved in the city management this paper states that;

Hypothesis $\mathbf{2}\left(\mathbf{H}_{\mathbf{2}} \mathbf{)}\right.$ : There is a relationship between the city employees' evaluation of ICT platforms and the city employees' satisfaction with the use of these platforms.

\subsection{A Systems View of Cities and Citizens}

In 1950, Ludwig Von Bertalanffy [59] wrote that 'living systems are open systems, maintaining themselves in exchange of materials with environment, and in continuous building up and breaking down of their components' (p. 23). In the last decades, this definition, originally based on the study of living natural systems, has been extended to social and economic studies as a consequence of the extensive application of system thinking [60]. Among the different research streams that have contributed to the application of systems thinking for the study of social and economic dynamics, relevant stimuli have been offered by the Viable Systems Model (VSM) [61-67] and the Viable Systems Approach (VSA) [25,31,68-74]. More specifically, the first one has offered a general representation of social and economic organizations, based on the functioning of human nervous system [75-77], while the second one has updated the managerial knowledge by investigating the dimensions that affect systems' behaviours and choices and by offering a systems representation for every kind of organized entity aimed to survive in a specific domain [78-80].

Today, thanks to these relevant research streams, it is possible to study social and economic phenomena in light of system thinking. In such a line, several implications can be derived with reference to the management of the city as a social and economic system [81,82].

Specifically to investigate a city as system requires consideration of both internal and external conditions of functioning and, at same time, analysis of the elements that are able to affect the system's process of 'building up and breaking down of their components' ([59], p. 23). With reference to this 
and according to Caputo et al. [83], a relevant role is played by the technologies as 'instruments', able to improve the quality of the management and structuring of internal and external relationships of a city. In such a line, the impact of technology depends on the structural configuration of city and on the external dynamics able to affect the city's functioning [84].

As outlined by Verhoef et al. [85], the contribution of technology to city management can change as an effect of external dynamics. In the same direction, Di Fatta et al. [86] show that the ways in which users approach and use the ICT platforms is affected by the features of the environment in which the technology is used. With the aim to enrich previous contributions on users' perceptions about the ICT platforms as consequence of external dynamics with reference to the specific domain of city management, this paper aims to study the following hypotheses:

Hypothesis $\mathbf{3}\left(\mathbf{H}_{3}\right)$ : There is a relationship between the city localization (Region) and the city employees' satisfaction with the use of ICT platforms.

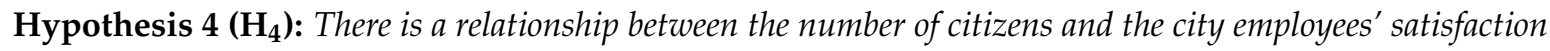
with the use of ICT platforms.

According to the systems perspective and by acting on the constructivist approach [87], it is necessary to specify that, in the study of the dimensions and dynamics that affect the role of information platforms for city management, it is required to consider the 'position' of the user in terms of specific spatial and time conditions able to affect their perceptions [88]. With reference to this, the vSA proposes the differences between the concepts of context and environment by specifying that 'the contexts are subjective and are functions of specific changes placed in a more objective and invariant environment' ([89], p. 232). By recognizing the relevance of this difference and its potential contribution to better investigate the city employees' perception about the use of ICT platforms, this paper aims to test the following hypothesis:

Hypothesis $\mathbf{5}\left(\mathbf{H}_{5}\right)$ : There is a relationship between the city size and the city employees' satisfaction with the use of ICT platforms.

\section{Method}

\section{Research Pathways and Data Collection}

The research is based on a questionnaire survey [90]. From August to October 2016, 7757 questionnaires were submitted via email to city employees of all municipalities, city halls, and city administrations in the whole Czech Republic, and 1033 questionnaires were completed with a response rate of $13.30 \%$. The questionnaire was defined on the basis of the literature review on the topic of information platforms, in light of Service Science and System Thinking. According to Sperber et al. [91], the questionnaire was written in English and it was translated into Czech before being sent via email to the city employees. After the survey, the results were translated into English.

As suggested by Champion and Sear [92], the questionnaires were sent with an accompanying letter in which all the aims of the research were explained and the anonymity of results was warranted.

According to Kothari [93], to avoid any order bias, the questionnaires were submitted at the same time and the results were analysed in order to verify if there were some differences between the first and later respondents. Any relevant order bias has been identified.

As shown in the following Tables 1-6 the data acquired via the questionnaire survey (see Appendix A) were analysed in order to define a clear framework around the investigated variables. 
Table 1. Descriptive data-Region.

\begin{tabular}{cccccc}
\hline Region & Frequency & Percentage & $\begin{array}{c}\text { Cumulative } \\
\text { Percentage }\end{array}$ & Distortion & $\begin{array}{c}\text { Standard } \\
\text { Deviation }\end{array}$ \\
\hline Prague & 31 & 3 & 3 & 0 & 0.5 \\
South Bohemia & 80 & 7.8 & 10.8 & 0 & 0.9 \\
South Moravia & 116 & 11.2 & 22 & -0.1 & 1 \\
Karlovy Vary & 21 & 2 & 24 & 0 & 0.4 \\
Vysočina & 90 & 8.7 & 32.8 & 0 & 0.9 \\
Hradec Králové & 67 & 6.5 & 39.2 & 0 & 0.8 \\
Liberec & 28 & 2.7 & 42 & 0 & 0.5 \\
Moravian-Silesian & 104 & 10.1 & 52 & 0 & 1 \\
Olomouc & 76 & 7.4 & 59.4 & 0 & 0.8 \\
Pardubice & 63 & 6.1 & 65.5 & 0 & 0.7 \\
Plzeň & 57 & 5.5 & 71 & 0 & 0.7 \\
Central Bohemian & 165 & 16 & 87 & 0 & 1.2 \\
Ústí na Labem & 66 & 6.4 & 93.4 & 0 & 0.8 \\
Zlín & 68 & 6.6 & 100 & 0 & 0.8 \\
Total & $\mathbf{1 0 3 2}$ & $\mathbf{1 0 0}$ & & 0 & 0 \\
\hline
\end{tabular}

Table 2. Descriptive data-Number of citizens.

\begin{tabular}{cccccc}
\hline $\begin{array}{c}\text { Number of } \\
\text { Citizens }\end{array}$ & Frequency & Percentage & $\begin{array}{c}\text { Cumulative } \\
\text { Percentage }\end{array}$ & Distortion & $\begin{array}{c}\text { Standard } \\
\text { Deviation }\end{array}$ \\
\hline $1-999$ & 576 & 55.8 & 55.8 & 0 & 1.6 \\
$1000-9999$ & 316 & 30.6 & 86.4 & 0 & 1.4 \\
$10,000-49,999$ & 86 & 8.3 & 94.8 & 0 & 0.9 \\
$50,000-99,999$ & 18 & 1.7 & 96.5 & 0 & 0.4 \\
$100,000-399,999$ & 24 & 2.3 & 98.8 & 0 & 0.5 \\
400,000 and more & 11 & 1.1 & 99.9 & 0 & 0.3 \\
Not Available & 1 & 0.1 & 100 & 0 & 0.1 \\
Total & $\mathbf{1 0 3 2}$ & $\mathbf{1 0 0}$ & & 0 & 0 \\
\hline
\end{tabular}

Table 3. Descriptive data-Kind of software.

\begin{tabular}{cccccc}
\hline Kind of Software & Frequency & Percentage & $\begin{array}{c}\text { Cumulative } \\
\text { Percentage }\end{array}$ & Distortion & $\begin{array}{c}\text { Standard } \\
\text { Deviation }\end{array}$ \\
\hline Information systems and other tools & 556 & 53.9 & 53.9 & 0 & 1.5 \\
MS Office or similar tools & 430 & 41.7 & 95.5 & 0.1 & 1.5 \\
Paper administration & 44 & 4.3 & 99.8 & 0 & 0.6 \\
Register of rights and obligations & 2 & 0.2 & 100 & 0 & 0.1 \\
Total & $\mathbf{1 0 3 2}$ & $\mathbf{1 0 0}$ & & 0 & 0 \\
\hline
\end{tabular}

Table 4. Descriptive data-City size.

\begin{tabular}{cccccc}
\hline City Size & Frequency & Percentage & $\begin{array}{c}\text { Cumulative } \\
\text { Percentage }\end{array}$ & Distortion & $\begin{array}{c}\text { Standard } \\
\text { Deviation }\end{array}$ \\
\hline $\begin{array}{c}\text { Municipality } \\
\text { Municipality of 2nd level }\end{array}$ & 675 & 65.4 & 65.4 & 0 & 1.5 \\
(authorized municipal office) & 171 & 16.6 & 82 & 0.1 & 1.2 \\
$\begin{array}{c}\text { Municipality of 3rd level } \\
\text { (Municipality with extended powers) }\end{array}$ & 184 & 17.8 & 99.8 & 0 & 1.2 \\
Romani Civic Association & 2 & 0.2 & 100 & 0 & 0.1 \\
Total & $\mathbf{1 0 3 2}$ & $\mathbf{1 0 0}$ & & 0 & 0 \\
\hline
\end{tabular}


Table 5. Descriptive data-Evaluation.

\begin{tabular}{cccccc}
\hline Evaluation & Frequency & Percentage & $\begin{array}{c}\text { Cumulative } \\
\text { Percentage }\end{array}$ & Distortion & $\begin{array}{c}\text { Standard } \\
\text { Deviation }\end{array}$ \\
\hline 1 & 91 & 16.4 & 16.4 & -0.1 & 1.6 \\
2 & 244 & 43.9 & 60.3 & 0 & 2 \\
3 & 180 & 32.4 & 92.6 & 0 & 2 \\
4 & 36 & 6.5 & 99.1 & 0 & 1 \\
5 & 5 & 0.9 & 100 & 0 & 0.4 \\
Total & $\mathbf{5 5 6}$ & $\mathbf{1 0 0}$ & & 0 & 0 \\
\hline
\end{tabular}

Table 6. Descriptive data-Satisfaction.

\begin{tabular}{cccccc}
\hline Satisfaction & Frequency & Percentage & $\begin{array}{c}\text { Cumulative } \\
\text { Percentage }\end{array}$ & Distortion & $\begin{array}{c}\text { Standard } \\
\text { Deviation }\end{array}$ \\
\hline 1 & 33 & 6.9 & 6.9 & 0 & 1.1 \\
2 & 158 & 33.3 & 40.2 & 0 & 2.1 \\
3 & 239 & 50.3 & 90.5 & 0 & 2.3 \\
4 & 36 & 7.6 & 98.1 & 0 & 1.2 \\
5 & 9 & 1.9 & 100 & 0 & 0.6 \\
Total & $\mathbf{4 7 5}$ & $\mathbf{1 0 0}$ & & 0 & 0 \\
\hline
\end{tabular}

After this, a correlation analysis was conducted in order to evaluate the relationships among the investigated variables, as shown in Table 7.

Table 7. Pearson Correlation.

\begin{tabular}{ccccccc}
\hline Variable & Region & City Size & $\begin{array}{c}\text { No of } \\
\text { Citizens }\end{array}$ & $\begin{array}{c}\text { Kind of } \\
\text { Software }\end{array}$ & Satisfaction & Evaluation \\
\hline Region & 1 & -0.045 & $-0.086^{*}$ & 0.006 & 0.067 & -0.043 \\
City size & -0.045 & 1 & $0.634^{*}$ & $-0.255^{*}$ & 0.019 & $0.126^{*}$ \\
Number of citizens & $-0.086^{*}$ & $0.634^{*}$ & 1 & $-0.211^{*}$ & 0.035 & $0.143^{*}$ \\
kind of software & 0.006 & $-0.255^{*}$ & $-0.211^{*}$ & 1 & $0.135^{*}$ & 0.027 \\
Satisfaction & 0.067 & -0.019 & -0.035 & $0.135 *$ & 1 & 0.345 \\
Evaluation & -0.043 & $0.126^{*}$ & $0.143^{*}$ & 0.027 & $0.345^{*}$ & 1 \\
\hline
\end{tabular}

* Coefficient is significant at the 0.01 level (two-tailed).

On the basis of the correlation analysis, the hypotheses were formalized, as shown in Table 8, and the conceptual model has been defined, as represented in Figure 1.

Table 8. Hypotheses.

\begin{tabular}{cc}
\hline Variables & Kind of Relationship \\
\hline Kind of software $\rightarrow$ Level of satisfaction & + \\
Evaluation of user interface $\rightarrow$ Level of satisfaction & + \\
Region $\rightarrow$ Level of satisfaction & + \\
Number of citizens $\rightarrow$ Level of satisfaction & + \\
City size $\rightarrow$ Level of satisfaction & + \\
\hline
\end{tabular}

Finally, the reliability of model was verified by measuring the Cronbach's alpha $(\alpha)$, the hypotheses were tested using the Structural Equation Modelling, and the fitness of the model was verified by measuring some fitness indexes, such as the Normed Fit Index (NFI), the Goodness of Fit Index (GFI), the Comparative Fit Index (CFI), and the Root Mean Square Error of Approximation (RMSEA). 


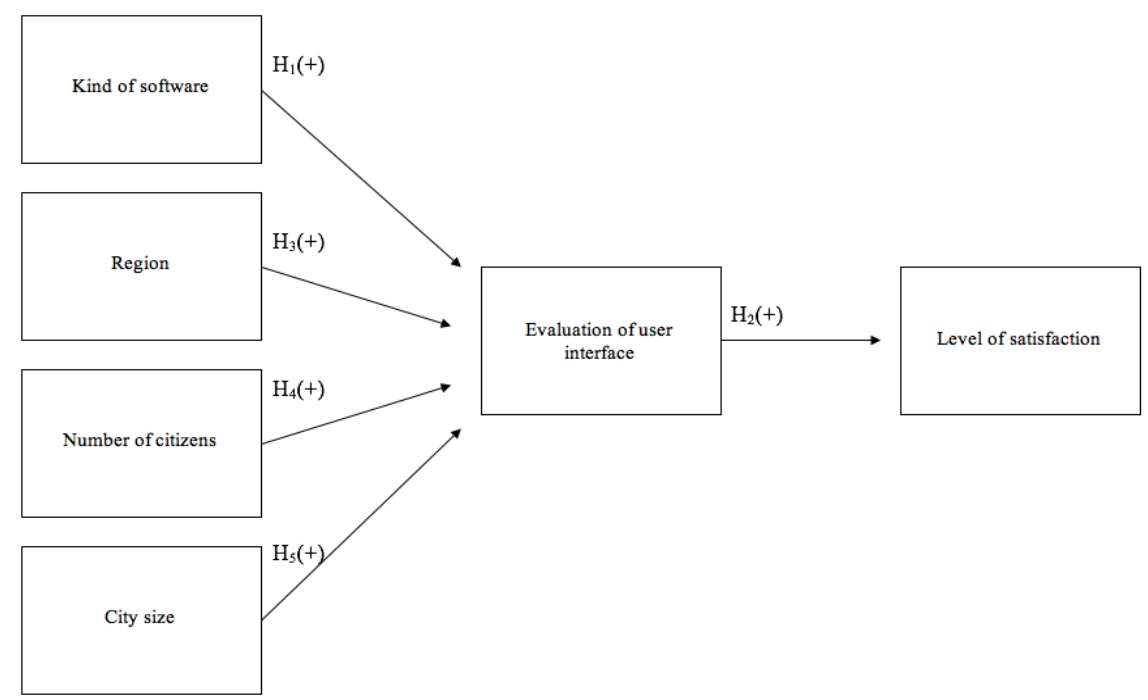

Figure 1. The conceptual model.

\section{Results}

\subsection{Reliability of Model}

As show in the following Table 9, the reliability of the model was verified by measuring the $\alpha$. According to Bland and Altman [94], an $\alpha$ equal to or higher than 0.7 demonstrates an acceptable reliability for the model. As presented in the following table, the $\alpha$ for all the variables is higher than 0.7.

Table 9. Cronbach's alpha $(\alpha)$.

\begin{tabular}{cc}
\hline Variables & Cronbach's Alpha $(\alpha)$ \\
\hline Region & 0.96 \\
City size & 0.84 \\
Number of citizens & 0.72 \\
kind of software & 0.73 \\
\hline
\end{tabular}

\subsection{Testing via Structural Equation Modelling}

The hypotheses have been tested using the SEM through IBM SPSS Statistics-Version 22. According to Baumgartner and Homburg [95], only the hypotheses with a probability value ( $p$-value) equal or higher than 0.6 have not been rejected. The results of SEM are reported in the following Table 10.

Table 10. Results of Structural Equation Modelling.

\begin{tabular}{ccc}
\hline & Hypothesis & $p$-Value \\
\hline $\mathrm{H}_{1}(+)$ & Kind of software $\rightarrow$ Level of satisfaction & 0.631 \\
$\mathrm{H}_{2}(+)$ & Evaluation of user interface $\rightarrow$ Level of satisfaction & 0.734 \\
$\mathrm{H}_{3}(+)$ & Region $\rightarrow$ Level of satisfaction & 0.682 \\
$\mathrm{H}_{4}(+)$ & Number of citizens $\rightarrow$ Level of satisfaction & 0.452 \\
$\mathrm{H}_{5}(+)$ & City size $\rightarrow$ Level of satisfaction & 0.789 \\
\hline
\end{tabular}

\subsection{Fitness Indexes}

In order to verify the fitness of the model, some fitness indexes, such as the Normed Fit Index (NFI), the Goodness of Fit Index (GFI), the Comparative Fit Index (CFI), and the Root Mean Square 
Error of Approximation (RMSEA), have been measured. As shown in the following Table 11, all the cut off values are respected. Therefore, the model can be accepted.

Table 11. Fitness indexes.

\begin{tabular}{ccc}
\hline Fitness Indexes & Value & Cut-Off Value \\
\hline Normed Fit Index (NFI) & 1.764 & $>0.90[96]$ \\
Goodness of Fit Index (GFI) & 1.027 & $>0.90[96]$ \\
Comparative Fit Index (CFI) & 1.402 & $>0.93[96]$ \\
Root Mean Square Error of & 0.073 & $<0.10[97]$ \\
Approximation (RMSEA) & & \\
\hline
\end{tabular}

\section{Discussion}

According to the results reported in the Table 10, with reference to the investigated sample, there is a positive relationship between the kind of ICT platform used and the city employees' satisfaction with the use of these platforms. Therefore, $\mathrm{H}_{1}$ is confirmed. This result is aligned with previous contributions offered with reference to the approach to digital platforms [98,99]. More specifically, as outlined by Mansfield [100], the technology can have different forms, and the capability of technology to solve a problem depends on the relationships between the users' perceptions and the technology's form. By reflecting on this result, it is possible to underline that the technology also has subjective dimensions related to the perceptions of users [101]. In such a line, from both theoretical and practical points of view, this result underlines the need for the definition of technological architecture to be included in the management of the city or, more generally, for the management of service systems to include the specific features of users [49].

In the same direction, the research also shows that there is a positive relationship between the city employees' evaluation of ICT platforms and the city employees' satisfaction with the use of these platforms. Therefore, $\mathrm{H}_{2}$ is confirmed. This result is also aligned with previous marketing studies about users' satisfaction in a service ecosystem [102,103]. More specifically, as underlined by Oliver [104], the evaluation of a service or a product represents the ways in which the user or consumer manifests their degree of satisfaction. This result does not offer a real advancement in knowledge to the previous managerial contributions, but it confirms that, with reference to the city employees' perception of the use of the ICT platform for the management of city, the relationship between evaluation and satisfaction is respected. With reference to this, the result underlines the need for policy makers to involve city employees in the planning of city informatics infrastructure, because only in this way it is possible to ensure an effective contribution of technology to the management of city and, consequentially, the emergence of a smart approach in the management of the city.

The research also shows that there is a positive relationship between the city localization (Region) and the city employees' satisfaction with the use of ICT platforms and that there is a positive relationship between the city size and the city employees' satisfaction with the use of ICT platforms. Therefore, $\mathrm{H}_{3}$ and $\mathrm{H}_{5}$ are accepted. These results can be considered clear evidence of the role of external environment in the process of evaluation for internal dynamics of service systems [105]. More specifically, the results underline that, in the management of informatics architecture for a service system, it is not enough to consider the internal dimensions, but it is also necessary to evaluate the environment in which the service system acts [106]. In the same direction, the results outline that the evaluation process, with reference to the ICT platforms, cannot be considered objective because it is affected by the context in which users live and work daily [107].

Unfortunately, not all the hypotheses are confirmed. In fact, as shown in the Table 11, there is not a positive relationship between the number of citizens and the city employees' satisfaction with the use of ICT platforms. Therefore, $\mathrm{H}_{4}$ is not confirmed. This result is partially misaligned with previous managerial contributions about the role of environmental structure in affecting users' perception and evaluation in the use of ICT platforms [108]. Despite this, the result can be explained in terms of 
standardization in users' perceptions [109]. More specifically, by considering that the investigated sample refers to a group in city more closed and affected by similar cultures, habits, and rules, it is possible to state that the number of citizens does not represent a discriminant factor in the definition of environment.

\section{Conclusions and Future Directions for Research}

As a consequence of social, economic, and technological dynamics, our era is strictly affected by the opportunities offered by computer science and by ICT [110-112]. The ICT platforms, tools, and environment are radically changing the structure of our society by supporting processes and dynamics unimaginable only few years ago $[113,114]$. By recognizing the relevance of 'digitalization' as relevant process for social and economic dynamics [115], this paper focuses its attention on the role that digital platforms can have in the management of the city as an example of a service system. In such a line, this paper investigates the ways in which the external environment and features of city employees can affect the evaluation of and the satisfaction of city employees with the use of ICT platforms.

By building on the assumption that technology represents a key pillar for the emergence and management of service systems, this paper aims to enrich previous contributions in the domain of service science and system thinking by analysing some relevant conditions for the effective use of technology. In accordance with this, the concept of the city is used to offer a tangible representation for the construct of a service system, and the city employees are analysed as examples of users involved in the managerial processes, in order to better understand their relationship with the technology and the role of technology in the management of service systems [116].

By stressing the theoretical reflections and the empirical findings herein, some theoretical and practical implications can be derived. Specifically, from a theoretical point of view, the paper underlines the need:

- $\quad$ to enrich studies in the domain of service systems in order to better understand the role of technology and its relationships with the user;

- to combine service science and system thinking as a useful interpretative lens for the understanding of social and economic dynamics;

- to increase the attention given to the study of the dimensions and processes that affect the perception of users involved in a service system.

At same time, from a practical point of view, this paper highlights the need:

- to develop multi- and trans-disciplinary studies to directly investigate the different elements able to affect the efficiency, effectiveness, and sustainability of technology in service systems;

- to compare the approach to the technology in different territorial and cultural environments in order to better understand the effect of the environment on the use of technology;

- $\quad$ to enrich competences and capabilities of policy makers in order to better approach technology on the basis of users' perceptions and expectations.

Despite the implications offered by this paper, the research cannot be considered exhaustive because it is affected by several limitations, such as the focus on a specific geographic area, the kind of users analysed, and the adoption of a single quantitative approach. In order to overcome these limitations, future steps are required to compare the results with reference to several geographic areas at different times, to enlarge the number of users analysed, and to validate the results by using others' quantitative and qualitative methods. Notwithstanding these limitations, this paper satisfies its aim to investigate the approach to the technology in the management of city as a service ecosystem. In such a line, it attracts the attention of researchers and practitioners to the relevant roles that users' perceptions and external environment can have on the contribution of technology to the management of service systems. 
Author Contributions: Francesco Caputo has written the Sections 1-4 while Leonard Walletzký has written the Sections 5 and 6.

Conflicts of Interest: The authors declare no conflict of interest.

Appendix A. Structure of Questionnaire Survey

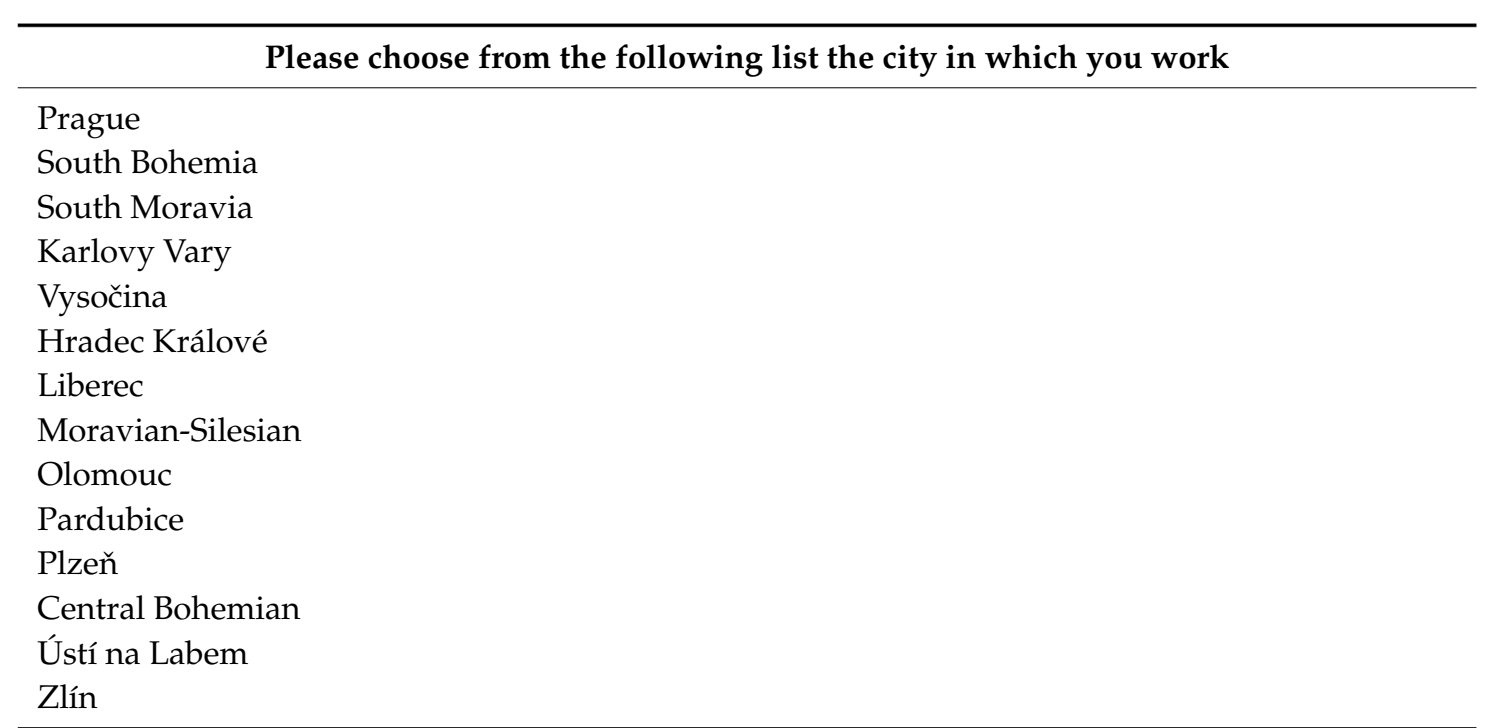

Please choose from the following list the class which represents the size of the city in which you work in terms of number of citizens

$1-999$
$1000-9999$
$10,000-49,999$
$50,000-99,999$
$100,000-399,999$
400,000 and more

Please choose from the following list the kind of software used in your activities for the management of the city

Information systems and other tools

MS Office or similar tools

Paper administration

RPP

Please choose from the following list the kind of city in which you work

Municipality

Municipality of 2nd level (authorized municipal office)

Municipality of 3rd level (Municipality with extended powers)

ROS

Please define your evaluation of the user interface of ICT adopted for city management activities by using a 5 point scale in which ' 1 means very low' and ' 5 means very high'

$\begin{array}{lllll}1 & 2 & 3 & 4 & 5\end{array}$

Please define your satisfaction with the use of ICT adopted for city management activities by using a 5 point scale in which '1 means very low' and '5 means very high'

$\begin{array}{lllll}1 & 2 & 3 & 4 & 5\end{array}$




\section{References}

1. Nam, T.; Pardo, T.A. Conceptualizing smart city with dimensions of technology, people, and institutions. In Proceedings of the 12th Annual International Digital Government Research Conference: Digital Government Innovation in Challenging Times, College Park, MD, USA, 12-15 June 2011; pp. 282-291.

2. Krugman, P. A model of innovation, technology transfer, and the world distribution of income. J. Political Econ. 1979, 87, 253-266. [CrossRef]

3. Arora, A.; Gambardella, A. The changing technology of technological change: General and abstract knowledge and the division of innovative labour. Res. Policy 1994, 23, 523-532. [CrossRef]

4. Christensen, C.M.; Horn, M.B.; Johnson, C.W. Disrupting Class: How Disruptive Innovation Will Change the Way the World Learns; McGraw-Hill: New York, NY, USA, 2008.

5. Lall, S. Technological capabilities and industrialization. World Dev. 1992, 20, 165-186. [CrossRef]

6. Goldman, S.L.; Nagel, R.N. Management, technology and agility: The emergence of a new era in manufacturing. Int. J. Technol. Manag. 1993, 8, 18-38.

7. Zahir Irani, P.E. The propagation of technology management taxonomies for evaluating investments in information systems. J. Manag. Inf. Syst. 2000, 17, 161-177.

8. Karimi, J.; Somers, T.M.; Gupta, Y.P. Impact of information technology management practices on customer service. J. Manag. Inf. Syst. 2001, 17, 125-158.

9. Caputo, F.; Evangelista, F.; Russo, G. Information Sharing and Communication Strategies: A Stakeholder Engagement view. In Innovation, Entrepreneurship and Digital Ecosystems; Vrontis, D., Weber, Y., Tsoukatos, E., Eds.; EuroMed Press: Cyprus, 2016; pp. 436-442.

10. Del Giudice, M.; Caputo, F.; Evangelista, F. How decision systems changing? The contribution of Social Media to the management decisional liquefaction. J. Decis. Syst. 2016, 25, 214-226.

11. Roco, M.C.; Bainbridge, W.S. The new world of discovery, invention, and innovation: Convergence of knowledge, technology, and society. J. Nanopart. Res. 2013, 15, 1-17. [CrossRef]

12. Krohn, W.; Layton, E.T., Jr.; Weingart, P. The Dynamics of Science and Technology: Social Values, Technical Norms and Scientific Criteria in the Development of Knowledge; Springer: New York, NY, USA, 2012.

13. Eshet, Y. Thinking in the digital era: A revised model for digital literacy. Issues Informing Sci. Inf. Technol. 2012, 9, 267-276.

14. Palfrey, J.; Gasser, U. Born Digital: Understanding the First Generation of Digital Natives; Basic Books: London, UK, 2013.

15. Leeflang, P.S.; Verhoef, P.C.; Dahlström, P.; Freundt, T. Challenges and solutions for marketing in a digital era. Eur. Manag. J. 2014, 32, 1-12. [CrossRef]

16. McMichael, P. Development and Social Change: A Global Perspective; Sage Publications: London, UK, 2016.

17. Pahl, G.; Beitz, W. Engineering Design: A Systematic Approach; Springer: New York, NY, USA, 2013.

18. Bijker, W.E.; Hughes, T.P.; Pinch, T.; Douglas, D.G. The Social Construction of Technological Systems: New Directions in the Sociology and History of Technology; MIT Press: Cambridge, MA, USA, 2012.

19. Rosner, L. The Technological Fix: How People Use Technology to Create and Solve Problems; Routledge: London, UK, 2013.

20. Parasuraman, A. Technology Readiness Index (TRI) a multiple-item scale to measure readiness to embrace new technologies. J. Serv. Res. 2000, 2, 307-320.

21. Maglio, P.; Bailey, J.; Gruhl, D. Steps toward a science of service systems. Computer 2007, 40, 71-77.

22. Maglio, P.P.; Spohrer, J. Fundamentals of service science. J. Acad. Mark. Sci. 2008, 36, 18-20. [CrossRef]

23. Spohrer, J.; Maglio, P.P. The emergence of service science: Toward systematic service innovations to accelerate co-creation of value. Prod. Oper. Manag. 2008, 17, 238-246. [CrossRef]

24. Vargo, S.L.; Akaka, M.A. Service-dominant logic as a foundation for service science: Clarifications. Serv. Sci. 2009, 1, 32-41. [CrossRef]

25. Barile, S.; Polese, F. Smart service systems and viable service systems: Applying systems theory to service science. Serv. Sci. 2010, 2, 21-40. [CrossRef]

26. Von Bertalanffy, L. General Systems Theory; Braziller: New York, NY, USA, 1968.

27. Checkland, P. Systems Thinking, Systems Practice; John Wiley \& Sons: Chichester, UK, 1981.

28. Checkland, P. Systems thinking. In Rethinking Management Information Systems; Oxford University Press: Oxford, UK, 1999; pp. 45-56. 
29. Emery, F.E. Systems Thinking: Selected Readings; Penguin Books: New York, NY, USA, 1981.

30. Forrester, J.W. System dynamics, systems thinking, and soft OR. Syst. Dyn. Rev. 1994, 10, 245-256. [CrossRef]

31. Golinelli, G.M. Viable Systems Approach (vSA): Governing Business Dynamics; Cedam: Padova, Italy, 2010.

32. Barile, S.; Saviano, M. Foundations of systems thinking: The structure-system paradigm. In Contributions to Theoretical and Practical Advances in Management. A Viable Systems Approach (vSA); Various Authors; International Printing: Avellino, Italy, 2011; pp. 1-24.

33. Evangelista, F.; Caputo, F.; Russo, G.; Buhnova, B. Voluntary corporate disclosure in the Era of Social Media. In The 4rd International Symposium Advances in Business Management. "Towards Systemic Approach"; E-Book Series; Caputo, F., Ed.; Business Systems: Avellino, Italy, 2016; pp. 124-128.

34. Holston, J. Cities and Citizenship; Duke University Press: New York, NY, USA, 1999.

35. Button, K. City management and urban environmental indicators. Ecol. Econ. 2002, 40, 217-233. [CrossRef]

36. Hambleton, R. The new city management. In Globalism and Local Democracy; Palgrave Macmillan: London, UK, 2003; pp. 147-168.

37. Yaojun, Y.A.N. On Grid Management in city management. Urban Probl. 2006, 2, 76-79.

38. Lusch, R.F. Reframing supply chain management: A service-dominant logic perspective. J. Supply Chain Manag. 2011, 47, 14-18. [CrossRef]

39. Castells, M. The Informational City: Information Technology, Economic Restructuring, and the Urban-Regional Process; Blackwell: Oxford, UK, 1989.

40. Bulu, M. Upgrading a city via technology. Technol. Forecast. Soc. Chang. 2014, 89, 63-67. [CrossRef]

41. Di Nauta, P.; Merola, B.; Caputo, F.; Evangelista, F. Reflections on the Role of University to Face the Challenges of Knowledge Society for the Local Economic Development. J. Knowl. Econ. 2015. [CrossRef]

42. Caputo, F.; Del Giudice, M.; Evangelista, F.; Russo, G. Corporate disclosure and intellectual capital. The light side of information asymmetry. Int. J. Manag. Financ. Account. 2016, 8, 75-96. [CrossRef]

43. Polese, F.; Caputo, F.; Carrubbo, L.; Sarno, D. The value (co)creation as peak of social pyramid. In Proceedings of the 26th Annual RESER Conference What's Ahead in Service Research: New Perspectives for Business and Society, Naples, Italy, 8-10 September 2016; pp. 1232-1248.

44. Gaspar, J.; Glaeser, E.L. Information technology and the future of cities. J. Urban Econ. 1998, 43, $136-156$. [CrossRef]

45. Shepard, M. Sentient City: Ubiquitous Computing, Architecture, and the Future of Urban Space; MIT Press: Cambridge, MA, USA, 2011.

46. Lee, J.H.; Phaal, R.; Lee, S.H. An integrated service-device-technology roadmap for smart city development. Technol. Forecast. Soc. Chang. 2013, 80, 286-306. [CrossRef]

47. Camagni, R.; Capello, R.; Nijkamp, P. Towards sustainable city policy: An economy-environment technology nexus. Ecol. Econ. 1998, 24, 103-118. [CrossRef]

48. Eade, J. Living the Global City: Globalization as Local Process; Routledge: London, UK, 2003.

49. Sawyer, S.; Eschenfelder, K.R. Social informatics: Perspectives, examples, and trends. Annu. Rev. Inf. Sci. Technol. 2002, 36, 427-465. [CrossRef]

50. Gurstein, M. Effective use: A community informatics strategy beyond the digital divide. First Monday $2003,8$. [CrossRef]

51. Anttiroiko, A.V.; Valkama, P.; Bailey, S.J. Smart cities in the new service economy: Building platforms for smart services. AI Soc. 2014, 29, 323-334. [CrossRef]

52. Liang, T.P.; Lai, H.J.; Ku, Y.C. Personalized content recommendation and user satisfaction: Theoretical synthesis and empirical findings. J. Manag. Inf. Syst. 2006, 23, 45-70. [CrossRef]

53. Tat-Kei Ho, A. Reinventing local governments and the e-government initiative. Public Adm. Rev. 2002, 62, 434-444. [CrossRef]

54. Lin, J.S.C.; Hsieh, P.L. The influence of technology readiness on satisfaction and behavioral intentions toward self-service technologies. Comput. Hum. Behav. 2007, 23, 1597-1615. [CrossRef]

55. Warner, M.E.; Hefetz, A. Managing markets for public service: The role of mixed public-private delivery of city services. Public Adm. Rev. 2008, 68, 155-166. [CrossRef]

56. Brady, M.K.; Knight, G.A.; Cronin, J.J.; Tomas, G.; Hult, M.; Keillor, B.D. Removing the contextual lens: A multinational, multi-setting comparison of service evaluation models. J. Retail. 2005, 81, 215-230. [CrossRef] 
57. Chin, W.W.; Lee, M.K. A proposed model and measurement instrument for the formation of IS satisfaction: The case of end-user computing satisfaction. In Proceedings of the Twenty First International Conference on Information Systems, Brisbane, Australia, 10-13 December 2000; pp. 553-563.

58. Swindell, D.; Kelly, J.M. Linking citizen satisfaction data to performance measures: A preliminary evaluation. Public Perform. Manag. Rev. 2000, 24, 30-52. [CrossRef]

59. Von Bertalanffy, L. The theory of open systems in physics and biology. Science 1950, 111, 23-29. [CrossRef] [PubMed]

60. Laszlo, E. The Systems View of the World a Holistic Vision for Our Time; Hampton Pr: London, UK, 1996.

61. Beer, S. The Heart of Enterprise; John Wiley \& Sons: New York, NY, USA, 1979.

62. Beer, S. The viable system model: Its provenance, development, methodology and pathology. J. Oper. Res. Soc. 1984, 35, 7-25. [CrossRef]

63. Espejo, R.; Harnden, R. The Viable System Model: Interpretations and Applications of Stafford Beer's VSM; Wiley: New York, NY, USA, 1989.

64. Espejo, R. The viable system model. Syst. Pract. Action Res. 1990, 3, 219-221. [CrossRef]

65. Schwaninger, M. Embodiments of organizational fitness: The Viable System Model (VSM) as a guide. Syst. Pract. 1990, 3, 249-264. [CrossRef]

66. Espejo, R.; Bowling, D.; Hoverstadt, P. The viable system model and the Viplan software. Kybernetes 1999, 28, 661-678. [CrossRef]

67. Leonard, A. The viable system model and knowledge management. Kybernetes 2000, 29, 710-715. [CrossRef]

68. Polese, F.; Carrubbo, L.; Russo, G. Managing Business Relationships: Between Service Culture and a Viable Systems Approach. Esperienze d'Impresa: Dipartimento Studi Ricerche Aziendali Università Salerno 2011, 2, 135-158.

69. Badinelli, R.; Barile, S.; Ng, I.; Polese, F.; Saviano, M.; Di Nauta, P. Viable service systems and decision making in service management. J. Serv. Manag. 2012, 23, 498-526. [CrossRef]

70. Golinelli, G.M.; Barile, S.; Saviano, M.; Polese, F. Perspective shifts in marketing: Toward a paradigm change? Serv. Sci. 2012, 4, 121-134. [CrossRef]

71. Pels, J.; Polese, F.; Brodie, R.J. Value co-creation: Using a viable systems approach to draw implications from organizational theories. Mercati Competitivita 2012, 1, 19-38.

72. Polese, F.; Di Nauta, P. A viable systems approach to relationship management in SD logic and service science. Bus. Adm. Rev. Schäffer-Poeschel 2013, 73, 113-129.

73. Saviano, M.; Caputo, F. Managerial choices between systems, knowledge and viability. In Contributions to Theoretical and Practical Advances in Management. A Viable Systems Approach (vSA), 2; Aracne: Roma, Italy, 2013; pp. 219-242.

74. Barile, S.; Saviano, M.; Caputo, F. How Are Markets Changing? The Emergence of Consumers Market Systems. In The 3rd International Symposium Advances in Business Management. "Towards Systemic Approach"; E-Book Series; Dominici, G., Ed.; Busyness Systems: Avellino, Italy, 2014; pp. 203-207.

75. Chroneer, D.; Mirijamdotter, A. Systems thinking benefits in supply change management: An illustration of the viable systems model in a Supply Chain. Int. J. Intell. Syst. Technol. Appl. 2009, 6, 227-248. [CrossRef]

76. Espejo, R.; Reyes, A. Organizational Systems: Managing Complexity with the Viable System Model; Springer: New York, NY, USA, 2011.

77. Yolles, M.; Fink, G. Agencies, normative personalities and the Viable Systems Model. J. Organ. Transf. Soc. Chang. 2013, 8, 83-116. [CrossRef]

78. Barile, S.; Saviano, M. An introduction to a value co-creation model, viability, syntropy and resonance in dyadic interaction. Syntropy 2013, 2, 69-89.

79. Iandolo, F.; Calabrese, M.; Antonucci, E.; Caputo, F. Towards a value co-creation based healthcare system. In The 2013 Naples Forum on Service. Service Dominant Logic, Networks E Systems Theory and Service Science: Integrating Three Perspective for a New Service Agenda; Giannini: Napoli, Italy, 2013.

80. Saviano, M.; Parida, R.; Caputo, F.; Kumar Datta, S. Health care as a worldwide concern. Insights on the Italian and Indian health care systems and PPPs from a vSA perspective. Euro. Med. J. Bus. 2014, 9, 198-220. [CrossRef]

81. Kafai, Y.B.; Resnick, M. Constructionism in Practice: Designing, Thinking, and Learning in a Digital World; Routledge: London, UK, 1996. 
82. Saviano, M.; Caputo, F.; Formisano, V.; Walletzký, L. From theory to practice in systems studies: A focus on Smart Cities. In The 4rd International Symposium Advances in Business Management. "Towards Systemic Approach"; Caputo, F., Ed.; Busyness Systems: Avellino, Italy, 2016; pp. 207-213.

83. Caputo, F.; Formisano, V.; Buhnova, B.; Walletzky, L. Beyond the digital ecosystems view: Insights from Smart Communities. In Innovation, Entrepreneurship and Digital Ecosystems; Vrontis, D., Weber, Y., Tsoukatos, E., Eds.; EuroMed Press: Cyprus, 2016; pp. 443-454.

84. Hodson, M.; Marvin, S. Can cities shape socio-technical transitions and how would we know if they were? Res. Policy 2010, 39, 477-485. [CrossRef]

85. Verhoef, P.C.; Lemon, K.N.; Parasuraman, A.; Roggeveen, A.; Tsiros, M.; Schlesinger, L.A. Customer experience creation: Determinants, dynamics and management strategies. J. Retail. 2009, 85, 31-41. [CrossRef]

86. Di Fatta, D.; Caputo, F.; Evangelista, F.; Dominici, G. Small world theory and the World Wide Web: Linking small world properties and website centrality. Int. J. Markets Bus. Syst. 2016, 2, 126-140. [CrossRef]

87. Von Glasersfeld, E. An introduction to radical constructivism. In The Invented Real; Watzlawick, P., Ed.; Norton: New York, NY, USA, 1984; pp. 17-40.

88. Doolittle, P.E.; Hicks, D. Constructivism as a theoretical foundation for the use of technology in social studies. Theory Res. Soc. Educ. 2003, 31, 72-104. [CrossRef]

89. Barile, S.; Carrubbo, L.; Iandolo, F.; Caputo, F. From 'EGO' to 'ECO' in B2B relationships. J. Bus. Market Manag. 2013, 6, 228-253.

90. Sudman, S.; Bradburn, N.M.; Schwarz, N. Thinking about Answers: The Application of Cognitive Processes to Survey Methodology; Jossey-Bass: New York, NY, USA, 1996.

91. Sperber, A.D.; Devellis, R.F.; Boehlecke, B. Cross-cultural translation methodology and validation. J. Cross Cult. Psychol. 1994, 25, 501-524. [CrossRef]

92. Champion, D.J.; Sear, A.M. Questionnaire response rate: A methodological analysis. Soc. Forces 1969, 335-339. [CrossRef]

93. Kothari, C.R. Research Methodology: Methods and Techniques; New Age International: London, UK, 2004.

94. Bland, J.M.; Altman, D.G. Statistics notes: Cronbach's alpha. BMJ 1997, 314, 572-591. [CrossRef] [PubMed]

95. Baumgartner, H.; Homburg, C. Applications of structural equation modeling in marketing and consumer research: A review. Int. J. Res. Market. 1996, 13, 139-161. [CrossRef]

96. Byrne, B.M. Structural Equation Modeling with EQS and EQS/Windows: Basic Concepts, Applications, and Programming; Sage: London, UK, 1994.

97. MacCallum, R.C.; Browne, M.W.; Sugawara, H.M. Power analysis and determination of sample size for covariance structure modeling. Psychol. Methods 1996, 1, 130-149. [CrossRef]

98. Suduc, A.M.; Bizoi, M.; Filip, F. Exploring multimedia web conferencing. Inform. Econ. 2009, 13, 5-17.

99. Shan, S.; Li, C.; Yao, W.; Shi, J.; Ren, J. An empirical study on critical factors affecting employee satisfaction. Syst. Res. Behav. Sci. 2014, 31, 447-460. [CrossRef]

100. Mansfield, E. International technology transfer: Forms, resource requirements, and policies. Am. Econ. Rev. 1975, 65, 372-376.

101. Taylor, S.; Todd, P.A. Understanding information technology usage: A test of competing models. Inf. Syst. Res. 1995, 6, 144-176. [CrossRef]

102. Love, P.E.; Irani, Z. An exploratory study of information technology evaluation and benefits management practices of SMEs in the construction industry. Inf. Manag. 2004, 42, 227-242. [CrossRef]

103. Powell, P. Information technology evaluation: Is it different? J. Oper. Res. Soc. 1992, 43, 29-42. [CrossRef]

104. Oliver, R.L. Satisfaction: A Behavioral Perspective on the Consumer; Routledge: London, UK, 2014.

105. Katz, D.; Kahn, R.L. The Social Psychology of Organizations; John Wiley \& Sons Inc.: New York, NY, USA, 1978.

106. Kettinger, W.J.; Lee, C.C. Perceived service quality and user satisfaction with the information services function. Decis. Sci. 1994, 25, 737-766. [CrossRef]

107. Sarkis, J.; Sundarraj, R.P. Factors for strategic evaluation of enterprise information technologies. Int. J. Phys. Distri. Logist. Manag. 2000, 30, 196-220. [CrossRef]

108. McKeen, J.D.; Guimaraes, T.; Wetherbe, J.C. The relationship between user participation and user satisfaction: An investigation of four contingency factors. Mis Q. 1994, 18, 427-451. [CrossRef]

109. Segars, A.H.; Grover, V. Re-examining perceived ease of use and usefulness: A confirmatory factor analysis. Mis Q. 1993, 17, 517-525. [CrossRef] 
110. Avgerou, C. The significance of context in information systems and organizational change. Inf. Syst. J. 2001, 11, 43-63. [CrossRef]

111. Van Der Aalst, W.M.; Ter Hofstede, A.H.; Weske, M. Business process management: A survey. In International Conference on Business Process Management; Springer: New York, NY, USA, 2003.

112. Chalmeta, R. Methodology for customer relationship management. J. Syst. Softw. 2006, 79, 1015-1024. [CrossRef]

113. Castells, M. The Network Society; Blackwell: Oxford, UK, 1996.

114. Drucker, P.F. The Age of Discontinuity: Guidelines to Our Changing Society; Transaction Publishers: London, UK, 2011.

115. Rannenberg, K.; Royer, D.; Deuker, A. The Future of Identity in the Information Society: Challenges and Opportunities; Springer: New York, NY, USA, 2009.

116. Caputo, F. A focus on company-stakeholder relationships in the light of the Stakeholder Engagement framework. In Innovation, Entrepreneurship and Digital Ecosystems; Vrontis, D., Weber, Y., Tsoukatos, E., Eds.; EuroMed Press: Cyprus, 2016; pp. 455-470.

(C) 2017 by the authors; licensee MDPI, Basel, Switzerland. This article is an open access article distributed under the terms and conditions of the Creative Commons Attribution (CC-BY) license (http://creativecommons.org/licenses/by/4.0/). 